\title{
Identification of Fusarium oxysporum f. sp. basilici Isolated from Soil, Basil Seed, and Plants by RAPD Analysis
}

\author{
Annalisa Chiocchetti, Stefano Ghignone, Andrea Minuto, M. Lodovica Gullino, Angelo Garibaldi, and \\ Quirico Migheli, Dipartimento di Protezione e Valorizzazione delle Risorse Agroforestali - Patologia vegetale, \\ Università di Torino, Via Leonardo da Vinci 44, I-10095 Grugliasco (TO), Italy
}

\begin{abstract}
Chiocchetti, A., Ghignone, S., Minuto, A., Gullino, M. L., Garibaldi, A., and Migheli, Q. 1999. Identification of Fusarium oxysporum f. sp. basilici isolated from soil, basil seed, and plants by RAPD analysis. Plant Dis. 83:576-581.

Fifty-two isolates of Fusarium oxysporum, obtained from infected basil plants, seed, flower residues, and soil from different growing areas in Italy and Israel, were analyzed by random amplified polymorphic DNA-polymerase chain reaction (RAPD-PCR), coupled to a DNA extraction protocol from colonies grown on Fusarium-selective medium. In a pathogenicity assay, 35 isolates caused 32 to $92 \%$ disease on seedlings of the highly susceptible basil cultivar Fine verde, while 17 isolates were nonpathogenic on basil. Thirty of the $F$. oxysporum $\mathrm{f}$. sp. basilici isolates obtained from soil or wilted plants gave identical amplification patterns using 31 different random primers. All tested primers allowed clear differentiation of $F$. oxysporum $\mathrm{f}$. sp. basilici from representatives of other formae speciales and from nonpathogenic strains of $F$. oxysporum. RAPD profiles obtained from DNA of isolates extracted directly from cultures grown on Fusarium selective medium were identical to those obtained from DNA extracted from lyophilized mycelia.
\end{abstract}

Additional keywords: diagnosis, DNA purification, Fusarium wilt, seed quality

Wilt and crown rot of sweet basil (Ocimum basilicum), caused by Fusarium oxysporum f. sp. basilici, represents a major problem on this crop, which is grown in Italy over a large area (approximately 80 ha) under glasshouse, mainly in the Riviera Ligure (5). First reported in Russia (12), F. oxysporum f. sp. basilici has been observed in Italy $(6,22)$, France (15), the United States $(1,2,7,24)$, and Israel (4). Control of this pathogen is complicated by the limited availability of registered fungicides. The only partially effective compounds are benzimidazoles, which are seldom applicable even as seed dressings because of frequent residues and inadequate levels of control $(5,18)$.

Corresponding author: Quirico Migheli

E-mail: migheli@ agraria.unito.it

Present address of Q. Migheli: Istituto di Patologia vegetale, Università di Sassari, Via E. De Nicola 9 , I-07100 Sassari, Italy.

This work was supported by Ministero per le Politiche Agricole (Piano Nazionale "Biotecnologie vegetali", Area 10 - I diagnostici, Programma $\mathrm{n}^{\circ} 451$ ) and by the National Research Council of Italy (Binational Project Italy - USA N. 97.00187. CT06). A. Chiocchetti acknowledges the receipt of a fellowship from Ministero dell'Ambiente.

Accepted for publication 8 March 1999.

Publication no. D-1999-0420-01R

(C) 1999 The American Phytopathological Society
Typically, basil Fusarium wilt management relies on the integration of different control measures, such as soil and substrate disinfestation, raised bench cultivation, seed dressing, and the use of antagonistic Fusarium spp. $(5,18,19,20)$. However, considerable potential for soil contamination and reinfestation through infected seed $(3,4,9,12,14)$ and airborne propagules (4) makes soil disinfestation only partially effective against $F$. oxysporum f. sp. basil$i c i$. Low efficacy of chemical control measures, the limited availability of resistant cultivars (21), and the unsatisfactory level of control sometimes offered by the commercially available formulations of biocontrol agents $(9,19)$ boost the urgency for seed and transplant certification procedures on sweet basil.

For this reason, new techniques are needed for rapid and sensitive detection of F. oxysporum f. sp. basilici and its differentiation from saprophytic and antagonistic Fusarium spp., which may be present in soil or as seed contaminants. All F. oxysporum f. sp. basilici isolates from Italy, Israel, and the United States tested so far belong to a single vegetative compatibility group $(3,8)$. Consequently, development of molecular tools should be facilitated in the case of $F$. oxysporum f. sp. basilici, which appears to be a specific clone of $F$. oxysporum.

The objective of this research was to design a reliable and rapid method for the unequivocal recognition of $F$. oxysporum $\mathrm{f}$. sp. basilici isolated from contaminated basil seed, plants, and infested soil. We report on the use of a random amplified polymorphic DNA-polymerase chain reaction (RAPD-PCR) $(23,25)$ technique coupled to a rapid protocol for DNA extraction from cultures grown on selective medium (16) to quickly identify $F$. oxysporum f. sp. basilici isolated from soil, basil seed lots, and plants.

\section{MATERIALS AND METHODS}

Fungal strains and culture media. Forty-six isolates of $F$. oxysporum were obtained in 1996 to 1998 from wilted basil, contaminated seed, or infested soil in 23 greenhouses at 17 sites in Italy. Six $F$. oxysporum f. sp. basilici isolates from Israel (coded FOB 024 through FOB 029) $(4,8)$ were included as references. The $F$. oxysporum f. sp. basilici isolates, nonpathogenic isolates, and representatives of different formae speciales of $F$. oxysporum used to compare RAPD profiles are listed in Table 1.

Isolation of Fusarium spp. from infested soil and wilted plants was carried out as described by Gamliel et al. (4) and by Elmer et al. (3) on Komada's Fusarium selective medium (11). Isolation from seed was done by placing on petri dishes (90 $\mathrm{mm}$ diameter) containing solidified Komada's medium 300 seeds (50 seeds per petri dish) randomly chosen from each of the following Italian basil seed lots (geographic origin of local ecotypes is indicated in parenthesis; commercial lots are produced by different farms and only the distributing company is indicated) Malavolti (Genova), Carnoli (Genova), Ramella autentico (Diano, IM), Filiberto fettine di carne (Diano, IM), Capra Nives autentico (Diano, IM), Armato autentico (Albenga, SV), Genovese gigante sel. San Remo (Ingegnoli, different origin), Genovese a foglia media (La Semiorto, different origin), Genovese sel. DSA (De Corato, different origin), Genovese Lot. Ba/09/51 (De Corato, different origin), Basilico genovese sel. SAIS (SAIS, different origin), Fine verde (Carrara, different origin), Aromatico violetto (Franchi, different origin). After 2 days of incubation at $30^{\circ} \mathrm{C}$, all $F$. oxysporum-like colonies were isolated, and from each colony, DNA was extracted and tested for pathogenicity on basil by using the RAPD technique as described in the following paragraphs. 
Table 1. Fusarium oxysporum isolates tested, source, geographic origin, and pathogenicity on basil (cv. Fine verde)

\begin{tabular}{|c|c|c|c|c|c|}
\hline Isolate & forma specialis & Source & Farm & Geographic origin & $\begin{array}{l}\text { Diseased plants } \\
\qquad(\% \pm \mathrm{SD})^{\mathrm{w}}\end{array}$ \\
\hline Noninoculated control & & & 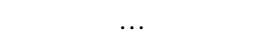 & 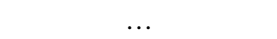 & $0 \mathrm{a}^{\mathrm{x}}$ \\
\hline FOB 001 & basilici & Soil & Ascheri Glass. 1 & Albenga, SV (Italy) & $84 \pm 2.7$ ef \\
\hline FOB 002 & basilici & Stem & Ascheri Glass. 1 & Albenga, SV (Italy) & $37 \pm 7.3 \mathrm{bc}$ \\
\hline FOB 003 & basilici & Stem & Ascheri Glass. 1 & Albenga, SV (Italy) & $51 \pm 13.7$ b-e \\
\hline FOB 004 & basilici & Soil & Ascheri Glass. 1 & Albenga, SV (Italy) & $80 \pm 9.9$ d-f \\
\hline FOB 005 & basilici & Stem & Ascheri Glass. 3 & Albenga, SV (Italy) & $40 \pm 11.9 \mathrm{bc}$ \\
\hline FOB 006 & basilici & Stem & Vigo Glass. 1 & Albenga, SV (Italy) & $62 \pm 8.2 \mathrm{~b}-\mathrm{f}$ \\
\hline FOB 007 & basilici & Stem & Vigo Glass. 2 & Albenga, SV (Italy) & $32 \pm 7.3 \mathrm{~b}$ \\
\hline FOB 008 & basilici & Stem & Mazzone G. Glass. & Diano, IM (Italy) & $67 \pm 12.6 \mathrm{c}-\mathrm{f}$ \\
\hline FOB 009 & basilici & Stem & Mazzone G. Glass. & Diano, IM (Italy) & $78 \pm 5.5 \mathrm{~d}-\mathrm{f}$ \\
\hline FOB 010 & basilici & Stem & Mazzone G. Tunn. & Diano, IM (Italy) & $62 \pm 19.0$ b-f \\
\hline FOB 011 & basilici & Stem & Capra N. & Diano, IM (Italy) & $81 \pm 4.7$ ef \\
\hline FOB 012 & basilici & Stem & Capra A. & Diano, IM (Italy) & $38 \pm 9.5 \mathrm{bc}$ \\
\hline FOB 013 & basilici & Stem & Ardissone R. & Diano, IM (Italy) & $45 \pm 2.7 \mathrm{~b}-\mathrm{d}$ \\
\hline FOB 014 & basilici & Stem & Casotti Glass. 1 & Voltri, GE (Italy) & $70 \pm 9.9 c-f$ \\
\hline FOB 015 & basilici & Stem & Sognato G. & Saguato, IM (Italy) & $65 \pm 2.7 \mathrm{~b}-\mathrm{f}$ \\
\hline FOB 016 & basilici & Stem & Casotti Glass. 2 & Voltri, GE (Italy) & $65 \pm 13.7 b-f$ \\
\hline FOB 017 & basilici & Soil & Lari & Lucca (Italy) & $57 \pm 4.7$ b-f \\
\hline FOB 018 & basilici & Stem & Risso F. Glass. 1 & Diano, IM (Italy) & $56 \pm 23.9 b-e$ \\
\hline FOB 019 & basilici & Stem & Risso F. Glass. 2 & Diano, IM (Italy) & $57 \pm 9.5$ b-f \\
\hline FOB 020 & basilici & Stem & Ardissone P. Glass. 1 & Diano, IM (Italy) & $70 \pm 5.5 \mathrm{c}-\mathrm{f}$ \\
\hline FOB 021 & basilici & Stem & Ardissone P. Glass. 2 & Diano, IM (Italy) & $83 \pm 2.7$ ef \\
\hline FOB 022 & basilici & Stem & Parodi U. & Diano Cast., IM (Italy) & $84 \pm 7.3$ ef \\
\hline FOB 023 & basilici & Stem & Ardissone R. & Diano, IM (Italy) & $67 \pm 4.7 \mathrm{c}-\mathrm{f}$ \\
\hline FOB $024 y$ & basilici & Stem & Hazeva & Israel & $62 \pm 14.2 \mathrm{~b}-\mathrm{f}$ \\
\hline FOB $025^{y}$ & basilici & Unknown & Besor & Israel & $59 \pm 14.5 \mathrm{~b}-\mathrm{f}$ \\
\hline FOB $026^{y}$ & basilici & Unknown & Avigdor & Israel & $71 \pm 19.0 \mathrm{c}-\mathrm{f}$ \\
\hline FOB $027^{y}$ & basilici & Unknown & Mazliakh & Israel & $79 \pm 21.4 \mathrm{~d}-\mathrm{f}$ \\
\hline FOB $028^{y}$ & basilici & Stem & Avigdor & Israel & $79 \pm 35.6 \mathrm{~d}-\mathrm{f}$ \\
\hline FOB $029^{y}$ & basilici & Stem & Besor & Israel & $78 \pm 11.0 \mathrm{~d}-\mathrm{f}$ \\
\hline FOB 030 & basilici & Soil & Lari & Lucca (Italy) & $60 \pm 9.9 \mathrm{~b}-\mathrm{f}$ \\
\hline FOB 031 & basilici & Seed & Ramella & Diano, IM (Italy) & $62 \pm 17.0 \mathrm{~b}-\mathrm{f}$ \\
\hline FOB 032 & basilici & Seed & Ramella & Diano, IM (Italy) & $70 \pm 2.7 \mathrm{c}-\mathrm{f}$ \\
\hline FOB 033 & basilici & Seed & Armato & Albenga, SV (Italy) & $86 \pm 0$ ef \\
\hline FOB 034 & basilici & Seed & Franchi & Bergamo (Italy) & $67 \pm 4.7 \mathrm{c}-\mathrm{f}$ \\
\hline FOB 035 & basilici & Seed & La Semiorto & Sarno, SA (Italy) & $92 \pm 7.3 \mathrm{f}$ \\
\hline FO 19/1 & Nonpathogenic & Basil soil & C.E.R.S.A.A. & Albenga, SV (Italy) & $5 \pm 4.7 \mathrm{a}$ \\
\hline FO 30/1 & Nonpathogenic & Basil soil & C.E.R.S.A.A. & Albenga, SV (Italy) & $10 \pm 9.5 \mathrm{a}$ \\
\hline FO 3/1 & Nonpathogenic & Basil seed & Ramella & Diano, IM (Italy) & $2 \pm 2.7 \mathrm{a}$ \\
\hline FO 3/4 & Nonpathogenic & Basil seed & Ramella & Diano, IM (Italy) & $0 \mathrm{a}$ \\
\hline FO 3/6 & Nonpathogenic & Basil seed & Ramella & Diano, IM (Italy) & $0 \mathrm{a}$ \\
\hline FO 3/7 & Nonpathogenic & Basil seed & Ramella & Diano, IM (Italy) & $0 \mathrm{a}$ \\
\hline FO $3 / 10$ & Nonpathogenic & Basil seed & Ramella & Diano, IM (Italy) & $0 \mathrm{a}$ \\
\hline FO 3/15 & Nonpathogenic & Basil seed & Ramella & Diano, IM (Italy) & $0 \mathrm{a}$ \\
\hline FO 3/16 & Nonpathogenic & Basil seed & Ramella & Diano, IM (Italy) & $5 \pm 8.2 \mathrm{a}$ \\
\hline FO 3/19 & Nonpathogenic & Basil seed & Ramella & Diano, IM (Italy) & $0 \mathrm{a}$ \\
\hline FO 3/29 & Nonpathogenic & Basil flower residues & Ramella & Diano, IM (Italy) & $0 \mathrm{a}$ \\
\hline FO 3/30 & Nonpathogenic & Basil flower residues & Ramella & Diano, IM (Italy) & $0 \mathrm{a}$ \\
\hline FO 3/31 & Nonpathogenic & Basil flower residues & Ramella & Diano, IM (Italy) & $0 \mathrm{a}$ \\
\hline FO 3/32 & Nonpathogenic & Basil flower residues & Ramella & Diano, IM (Italy) & $0 \mathrm{a}$ \\
\hline FO 3/33 & Nonpathogenic & Basil flower residues & Ramella & Diano, IM (Italy) & $3 \pm 2.7 \mathrm{a}$ \\
\hline FO 3/34 & Nonpathogenic & Basil flower residues & Ramella & Diano, IM (Italy) & $0 \mathrm{a}$ \\
\hline FO 3/35 & Nonpathogenic & Basil flower residues & Ramella & Diano, IM (Italy) & $0 \mathrm{a}$ \\
\hline FO $251 / 2$ & Nonpathogenic & Carnation rhizosphere & C.E.R.S.A.A. & Albenga, SV (Italy) & $\mathrm{NT}^{\mathrm{z}}$ \\
\hline FO 233/1 & Nonpathogenic & Carnation rhizosphere & C.E.R.S.A.A. & Albenga, SV (Italy) & NT \\
\hline Ragusa 2 & canariensis & Stem & Unknown & Ragusa (Italy) & NT \\
\hline FOCep 1 & cepae & Bulb & Unknown & Torino (Italy) & NT \\
\hline FOCy & cyclaminis & Corm & Michero & Albenga, SV (Italy) & NT \\
\hline FOD 1/1 & dianthi & Stem & C.E.R.S.A.A. & Albenga, SV (Italy) & NT \\
\hline $8 / 109$ & dianthi & Stem & C.E.R.S.A.A. & Albenga, SV (Italy) & NT \\
\hline FOG & gladioli & Corm & Unknown & Ormea, CN (Italy) & NT \\
\hline FOLi 1 & lilii & Corm & Unknown & Bagnasco, CN (Italy) & NT \\
\hline FOL race 2 & lycopersici & Stem & Unknown & Albenga, SV (Italy) & NT \\
\hline FOM1 & melonis & Stem & Unknown & Tortona, AL (Italy) & NT \\
\hline FORL 1 & radicis-lycopersici & Crown & Leone & Toirano, SV (Italy) & NT \\
\hline FOP R3 & pisi & Stem & Unknown & Napoli (Italy) & NT \\
\hline FOT Nervo & tulipae & Stem & Unknown & Albenga, SV (Italy) & NT \\
\hline
\end{tabular}

${ }^{\mathrm{w}}$ Results are expressed as the percent diseased plants at the end of the experiment (21 days after sowing).

${ }^{\mathrm{x}}$ Values followed by the same letter do not differ significantly according to the Student-Newman-Keuls test $(P<0.05)$.

y Kindly provided by Talma Katan, ARO Volcani Center, Bet Dagan, Israel.

${ }^{\mathrm{z}}$ Not tested. 
Fungal strains were grown on potato dextrose agar (PDA; Merck, Darmstadt, Germany) and maintained under mineral oil (Sigma, St. Louis, MO) at $12^{\circ} \mathrm{C}$.
Pathogenicity test. A pathogenicity assay was conducted to determine pathogenicity of all $F$. oxysporum isolates. Each isolate was grown in a 250-ml Erlenmeyer

Table 2. Code and sequence of the 31 primers selected for identification of Fusarium oxysporum $\mathrm{f}$. sp. basilici by random amplified polymorphic DNA-polymerase chain reaction (RAPD-PCR), with total number of informative DNA amplimers obtained with each primer in RAPD experiments

\begin{tabular}{llcc}
\hline Code & $\begin{array}{c}\text { Sequence } \\
\left(\mathbf{5}^{\prime} \rightarrow \mathbf{3}^{\prime}\right)\end{array}$ & $\begin{array}{c}\text { Informative } \\
\mathbf{a m p l i m e r s}\end{array}$ & $\begin{array}{c}\text { Size range } \\
(\mathbf{k b})\end{array}$ \\
\hline OPB-01 & GTTTCGCTCC & 4 & $0.4-2.4$ \\
OPB-02 & TGATCCCTGG & 2 & $0.7-1.0$ \\
OPB-03 & CATCCCCCTG & 2 & $0.6-2.0$ \\
OPB-04 & GGACTGGAGT & 2 & $0.4-1.5$ \\
OPB-05 & TGCGCCCTTC & 3 & $0.9-1.8$ \\
OPB-06 & TGCTCTGCCC & 2 & $0.7-1.0$ \\
OPB-07 & GGTGACGCAG & 2 & $0.5-1.0$ \\
OPB-08 & GTCCACACGG & 1 & 1.0 \\
OPB-10 & CTGCTGGGAC & 2 & $0.5-1.2$ \\
OPB-11 & GTAGACCCGT & 4 & $0.5-2.5$ \\
OPB-12 & CCTTGACGCA & 2 & $0.8-1.7$ \\
OPB-13 & TTCCCCCGCT & 3 & $0.5-1.7$ \\
OPB-14 & TCCGCTCTGG & 3 & $0.5-1.4$ \\
OPB-15 & GGAGGGTGTT & 1 & 1.0 \\
OPB-16 & TTTGCCCGGA & 3 & $0.9-2.5$ \\
OPB-17 & AGGGAACGAG & 6 & $0.5-2.1$ \\
OPB-18 & CCACAGCAGT & 4 & $0.7-1.9$ \\
OPB-19 & ACCCCCGAAC & 1 & 0.8 \\
OPE-01 & CCCAAGGTCC & 2 & $0.9-1.2$ \\
OPE-02 & GGTGCGGGAA & 2 & $0.6-2.0$ \\
OPE-04 & GTGACATGCC & 2 & $1.6-1.8$ \\
OPE-05 & TCAGGGAGGT & 3 & $0.8-3.0$ \\
OPE-07 & AGATGCAGCC & 2 & $1.0-1.2$ \\
OPE-09 & CTTCACCCGA & 1 & 1.0 \\
OPE-11 & GAGTCTCAGG & 1 & 1.0 \\
OPE-12 & TTATCGCCCC & 2 & $0.8-1.2$ \\
OPE-13 & CCCGATTCGG & 1 & 0.6 \\
OPE-14 & TGCGGCTGAG & 3 & $0.7-1.4$ \\
OPE-15 & ACGCACAACC & 4 & $0.3-2.1$ \\
OPE-16 & GGTGACTGTG & 3 & $0.4-3.0$ \\
OPE-17 & CTACTGCCGT & 1 & 1.7 \\
\hline & & & \\
\hline
\end{tabular}

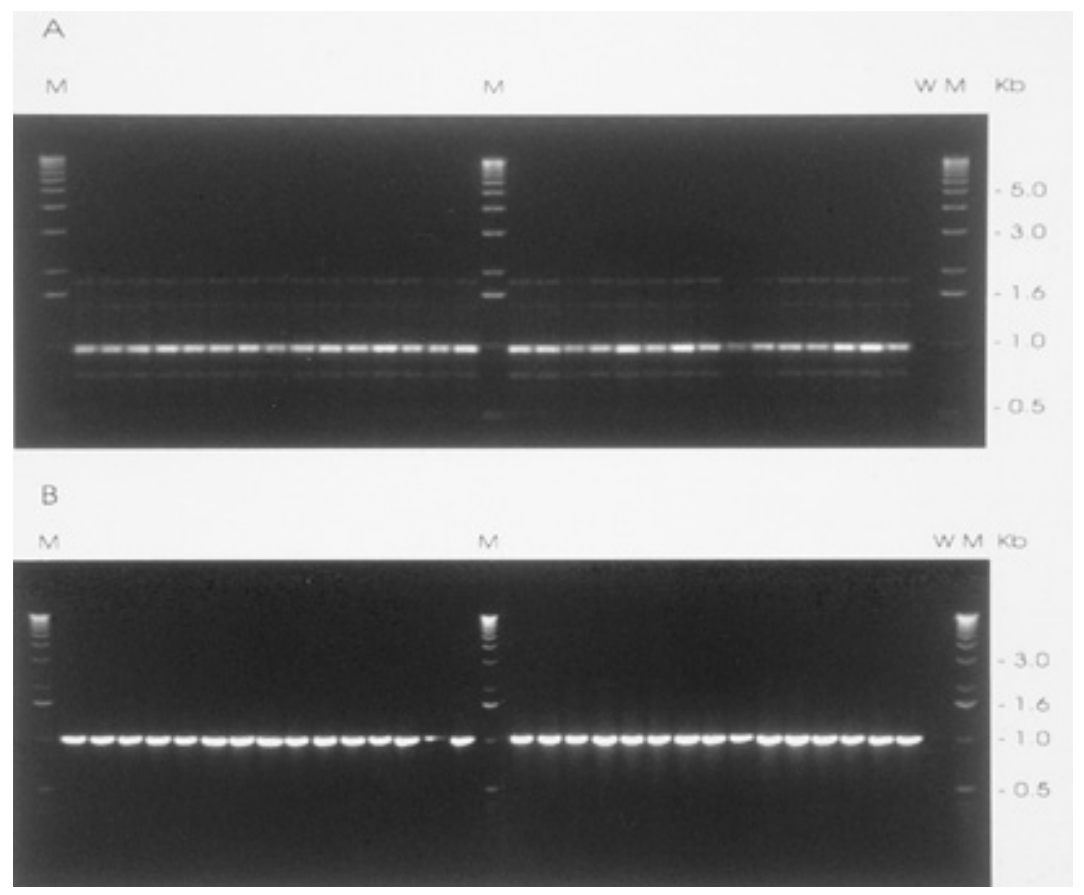

Fig. 1. Random amplified polymorphic DNA (RAPD) pattern obtained from 30 isolates of Fusarium oxysporum f. sp. basilici (FOB 001 through FOB 030) with primer OPB-06 (A) and OPB-08 (B). M: molecular weight marker (1 kb DNA Ladder; Life Technologies, Gaithersburg, MD); W: water control. Molecular weight in $\mathrm{kb}$ of some marker bands is specified on the right margin.

flask containing $100 \mathrm{ml}$ of potato dextrose broth (PDB; Merck; $24 \mathrm{~g} \mathrm{liter}^{-1}$ ) and yeast extract (Merck; $5 \mathrm{~g} \mathrm{liter}^{-1}$ ) with shaking $(150 \mathrm{rpm})$ at $26^{\circ} \mathrm{C}$ under constant light. After 7 days, fungal cultures were aseptically filtered through four layers of cheesecloth, and conidia were counted and homogeneously dispersed in a steam-disinfested substrate (Turco, Albenga, Italy) composed of 60:10:20:10 peat moss: composted pine and poplar bark:composted cattle manure:clay ( $\mathrm{vol} / \mathrm{vol} / \mathrm{vol} / \mathrm{vol})$ amended with $\mathrm{KNO}_{3} \quad\left(0.3 \mathrm{~g}\right.$ liter $\left.{ }^{-1}\right)$, $\mathrm{KH}_{2} \mathrm{PO}_{4}\left(0.18 \mathrm{~g} \mathrm{liter}^{-1}\right)$, and $\mathrm{NH}_{4} \mathrm{NO}_{3}(0.3$ $\mathrm{g}$ liter $\left.^{-1}\right)$. Final cell density was $10^{6} \mathrm{CFU}$ $\mathrm{cm}^{-3}$. Plastic pots $(10 \mathrm{~cm}$ diameter, 1 liter capacity) were filled with infested substrate. Twenty-five seeds of the cv. Fine verde $(O$. basilicum var. minimum, S.A.I.S., Cesena, Italy), highly susceptible to Fusarium wilt (5), were sown in each pot and covered with a thin layer of infested substrate. Three replicate pots were used for each isolate. The infested pots were watered daily and kept in a growth chamber $\left(25\right.$ to $28^{\circ} \mathrm{C}$, relative humidity 50 to $90 \%$, daily light conditions: $12-\mathrm{h}$ photoperiod, 50 to $60 \mathrm{kLux} \mathrm{m}^{-2}$ ).

Disease incidence was evaluated weekly by counting the number of emerged, healthy, and diseased seedlings. Control seedlings were grown in noninfested soil and maintained under the same conditions. Results are expressed as the percentage of seedlings showing symptoms of Fusarium wilt and nonemerged seedlings at the end of the experiment (21 days after sowing). The data were subjected to an analysis of variance followed by Student-NewmanKeuls multiple comparison test $(P=0.05)$ contained in the SPSS program (SPSS Inc., Chicago, IL). Each isolate was tested at least two times.

DNA extraction and RAPD-PCR conditions. In the first series of experiments, DNA was purified from lyophilized mycelium by a miniprep method as previously described (17), diluted 1:100 with TE, $\mathrm{pH}$ 8.0 (13), and used as template. RAPD analysis was carried out with the first $30 \mathrm{~F}$. oxysporum f. sp. basilici isolates listed in Table 1 (FOB 001 through FOB 030) to evaluate the homogeneity of their amplification profiles.

RAPD profiles obtained from five selected $F$. oxysporum f. sp. basilici isolates (FOB 001, FOB 002, FOB 003, FOB 004, and FOB 005) with selected primers (OPB02, OPB-08, OPB-11, and OPE-11; Operon Technologies Inc., Alameda, CA) were compared with those produced by representatives of other formae speciales and by nonpathogenic $F$. oxysporum isolates.

In the following assay, RAPD profiles were obtained with primers OPB-02, OPB06, OPB-08, OPE-02, OPE-05, or OPE-11 from Fusarium colonies isolated on Komada's selective medium from soil, diseased basil plants, or contaminated seed 
and compared with those produced by $F$. oxysporum f. sp. basilici isolates FOB 001, FOB 002, and FOB 003. DNA was directly extracted from agar cultures by following a 25-min extraction protocol (16). Briefly, mycelium-agar plugs $\left(50 \mathrm{mg}, 1 \mathrm{~cm}^{2}\right)$ were cut with a sterile scalpel from 2-day-old Fusarium colonies grown on Komada's selective medium and crushed in $1.5-\mathrm{ml}$ Eppendorf tubes with a glass rod in 150 $\mu \mathrm{l}$ of TE, $\mathrm{pH} 8.0$ (13). The tubes were then freeze-thawed three times by dipping in liquid nitrogen and then in boiling water, incubated for $15 \mathrm{~min}$ at $95^{\circ} \mathrm{C}$, and centrifuged for $5 \mathrm{~min}$ at $3,000 \times g$. The supernatant was then extracted once with an equal volume of chloroform:isoamyl alcohol (24:1), diluted 1:50 with sterile double-distilled water, and used as template DNA.

RAPD-PCR was carried out in $15 \mu \mathrm{l}$ of reaction mix containing $10 \mathrm{mM}$ Tris- $\mathrm{HCl}$, $\mathrm{pH}$ 9.0, $1.5 \mathrm{mM} \mathrm{MgCl}_{2}, 50 \mathrm{mM} \mathrm{KCl}, 0.1 \%$ Triton X-100, $0.01 \%$ (wt/vol) gelatin, 60 $\mu \mathrm{M}$ each of dATP, dCTP, dGTP, and dTTP, $5 \mathrm{pM}$ primer, about $0.2 \mathrm{ng}$ of template DNA, and 0.75 U of SuperTaq DNA polymerase (HT Biotechnology, Cambridge, UK). Thirty-one 10-mer oligonucleotides (Operon; Table 2) were tested as primer sequences. Reagents (without DNA) were combined into a premixture, and aliquots were pipetted into reaction 0.5-ml Eppendorf tubes before the addition of template DNA to minimize the risk of cross-contamination. Amplification was performed in a Perkin-Elmer Cetus (Norwalk, CT) Gene Amp PCR System 9600 programmed for one cycle of $2.5 \mathrm{~min}$ at $94^{\circ} \mathrm{C}, 45$ cycles of $30 \mathrm{~s}$ at $94^{\circ} \mathrm{C}, 1 \mathrm{~min}$ at $36^{\circ} \mathrm{C}, 2 \mathrm{~min}$ at $72^{\circ} \mathrm{C}$, with no ramping, followed by one cycle of $5 \mathrm{~min}$ at $72^{\circ} \mathrm{C}$. RAPD analysis was done at least three times for each isolate. Half of the reaction product was loaded in a $1.5 \%$ SeaKem LE agarose (FMC BioProducts, Rockland, ME) gel containing $0.5 \mu \mathrm{g}$ of ethidium bromide per $\mathrm{ml}$. Electrophoresis was performed for $1 \mathrm{~h}$ at $8.5 \mathrm{~V} \mathrm{~cm}^{-1}$ or for $15 \mathrm{~h}$ at $0.8 \mathrm{~V} \mathrm{~cm}^{-1}$ in $1 \times$ TAE (13) running buffer, and amplimers were directly viewed over a UV light source. Gel images were acquired with a Gel Doc 1000 System (Bio-Rad Laboratories, Hercules, CA).

\section{RESULTS}

Pathogenicity of $F$. oxysporum f. sp. basilici isolates on sweet basil. The $35 \mathrm{~F}$. oxysporum f. sp. basilici isolates generated 32 to $92 \%$ disease on seedlings after 21 days in infested substrate (Table 1). The first symptoms of seedling wilt appeared 10 days after sowing. Seventeen $F$. oxysporum isolates from basil seed, flower residues, or soil (Table 1), which did not share the same RAPD profile as $F$. oxysporum f. sp. basilici, did not differ statistically from the noninoculated control in the percentage of diseased seedlings at the end of the experiment (Table 1).
RAPD-PCR analysis. Identical RAPD patterns were obtained from the $F$. oxysporum f. sp. basilici isolates FOB 001 to FOB 030 with all 31 primers listed in Table 2. The molecular size of amplicons ranged from 0.3 to $3 \mathrm{~kb}$. The amplification patterns were always consistently reproducible in different experiments. Representative results are given in Figure 1.

RAPD analysis using all of the primers tested (OPB-02, OPB-08, OPB-11, and OPE-11) clearly distinguished $F$. oxysporum f. sp. basilici isolates from the other F. oxysporum isolates tested (Fig. 2).

The primer OPB-08, which gave rise to a main amplification product of $1.0 \mathrm{~kb}$ (Figs. $1 \mathrm{~B}$ and 2A), was selected as the most suitable in $F$. oxysporum f. sp. basilici identification by using the RAPD technique.
RAPD profiles obtained from template DNA directly extracted from $F$. oxysporum f. sp. basilici cultured on Komada's selective medium were identical to those obtained by using DNA purified from lyophilized mycelium (Fig. 3). Thus, this fast method of DNA extraction was adopted in the RAPD identification of $F$. oxysporum $\mathrm{f}$ sp. basilici isolated from basil seed by using primer OPB-08. Thirteen seed lots were tested, and five isolates of $F$. oxysporum f. sp. basilici were identified in four different lots (Ramella autentico, Armato autentico, Aromatico violetto, Genovese a foglia media; Table 1). In addition, 15 nonpathogenic $F$. oxysporum isolates recovered from seed or from flower residues of the lot Ramella autentico (Table 1) showed RAPD profiles that
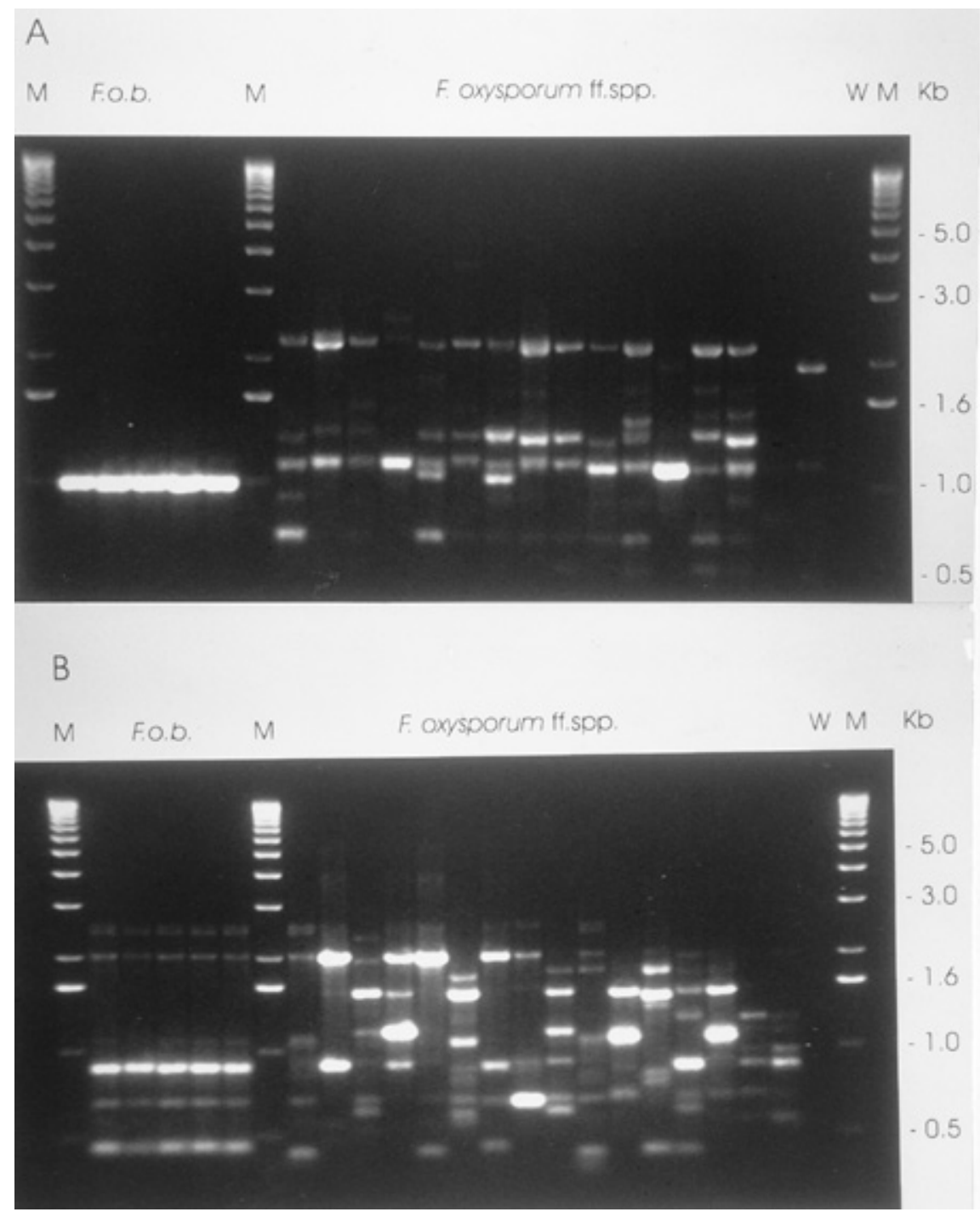

Fig. 2. Comparison of random amplified polymorphic DNA (RAPD) patterns obtained with primers OPB-08 (A) and OPB-11 (B) from Fusarium oxysporum (from left to right): f. sp. basilici isolates FOB 001, FOB 002, FOB 003, FOB 004, and FOB 005; f. sp. dianthi isolate FOD1/1; f. sp. canariensis isolate Ragusa2; f. sp. radicis-lycopersici isolate FORL 1; f. sp. gladioli isolate FOG; f. sp. cyclaminis isolate FOCy; f. sp. lycopersici isolate FOL race 2; f. sp. melonis isolate FOM1; f . sp. lilii isolate Foli 1; f. sp. cepae isolate FOCep1; f. sp. pisi isolate FOP R3; f. sp. tulipae isolate FOT Nervo, nonpathogenic isolates of $F$. oxysporum 233/1, 251/2; f. sp. dianthi isolate 8/109, nonpathogenic isolates of F. oxysporum 19/1 and 30/1. M: molecular weight marker (Fig. 1); W: water control. Molecular weight in $\mathrm{kb}$ of some marker bands is specified on the right margin. 


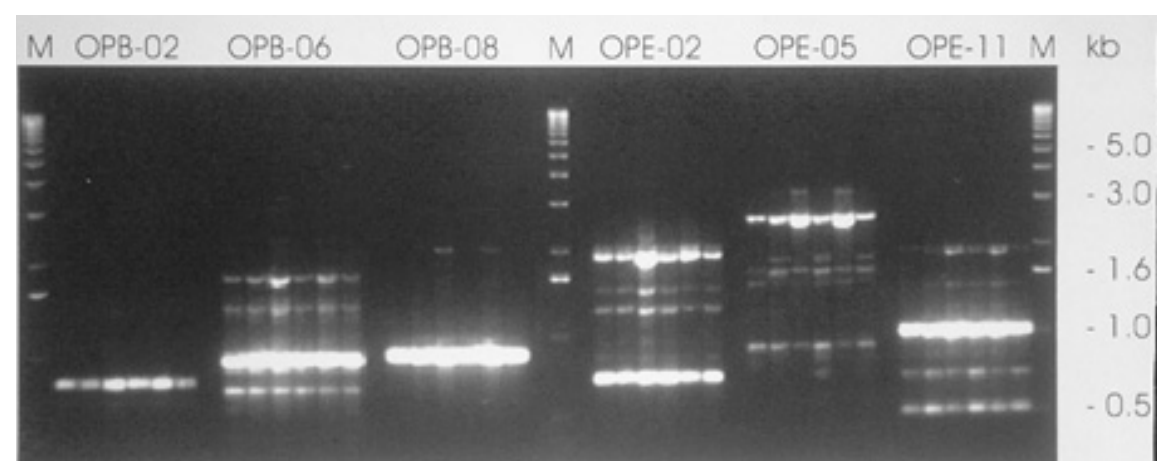

Fig. 3. Comparison of random amplified polymorphic DNA (RAPD) patterns obtained with primers OPB-02, OPB-06, OPB-08, OPE-02, OPE-05 and OPE-11 from three isolates of Fusarium oxysporum f. sp. basilici (FOB 001, FOB 002, and FOB 003). Each cluster of six lanes shows the amplification product obtained with DNA extracted from lyophilized mycelia (3 lanes on the left) or from colonies grown on Fusarium selective medium (3 lanes on the right). M: molecular weight marker (Fig. 1). Molecular weight in kb of some marker bands is specified on the right margin.

were all different from that obtained in the case of $F$. oxysporum f. sp. basilici (not shown).

\section{DISCUSSION}

The high infectious potential of $F$. oxysporum f. sp. basilici, which can be easily disseminated by both airborne and seedborne inoculum, requires development of an integrated approach toward all the different inoculum sources at various sites before, during, and after planting $(4,5)$. Primary inoculum sources, such as infested seed and transplants, should be promptly identified, and the use of certified propagative material is highly recommended to growers with noninfested glasshouses (3). In Italy, some seed companies have started testing seeds for $F$. oxysporum f. sp. basil$i c i$ contamination and are now selling seed certified as $F$. oxysporum f. sp. basilicifree (5). Nuclear seed is distributed to selected growers to produce larger amounts of disease-free basic seed and eventually certified seed stocks for commercial use.

By the procedure currently used (isolation on Fusarium-selective medium), it is impossible to discriminate among pathogenic and nonpathogenic $F$. oxysporum: seed lots are frequently discarded because they generate $F$. oxysporum and cannot be certified. These seed lots are often infested by nonpathogenic biotypes of the fungus, which cannot be distinguished from the pathogenic ones by the simple observation of morphological traits. The increasing adoption of biocontrol products based on antagonistic $F$. oxysporum (19) will certainly result in a high concentration of propagules of these beneficial microorganisms in the propagative material, thus hampering a correct diagnosis. Testing of each $F$. oxysporum isolate on the host plant would require 3 to 4 weeks and is economically impracticable. Hence, a rapid and reliable method for $F$. oxysporum f. sp. basilici detection in seed, transplants, and soil could find application in disease management for this crop.
During this study, 10 representative $F$. oxysporum f. sp. basilici isolates from our collection were assigned to the single VCG previously described as encompassing all the tested isolates from Italy, Israel, and the United States. Formerly, this group was designated VCG 0160 (8), but because of code-number overlapping with another forma specialis (10), it has recently been renumbered VCG 0200 (T. Katan, personal communication). The hypothesis that infested seed is spreading a clonal population of $F$. oxysporum f. sp. basilici internationally $(3,8,14)$, and that all $F$. oxysporum $\mathrm{f}$. sp. basilici isolates from Italy, Israel, and the United States tested so far belong to VCG 0200, strongly supports the feasibility and reliability of diagnostic tools based on genetic traits.

The method described here for template DNA extraction directly from agar cultures allows the complete analysis of 30 to 40 isolates (from DNA extraction to UV visualization of $F$. oxysporum f. sp. basilicispecific amplicons in the gel) in less than 8 h. Very little mycelium is required, and Komada's selective medium does not inhibit DNA amplification. This makes it possible to perform the RAPD-PCR test with one or two selected primers from colonies developing from contaminated seeds or plant tissue after 1 to 2 days incubation at room temperature.

The purification, cloning, and sequencing of selected amplicons is now being performed and will allow the development of $F$. oxysporum f. sp. basilici-specific primers to be used in a fast and reliable screening of pathogenic isolates by PCR.

\section{ACKNOWLEDGMENTS}

The authors wish to thank Talma Katan for providing $F$. oxysporum f. sp. basilici isolates from Israel, for performing VCG analysis of some of the isolates, and for critically reviewing the manuscript.

\section{LITERATURE CITED}

1. Davis, R. M., Marshall, K. D., and Valencia, J. 1993. First report of Fusarium wilt of basil in California. Plant Dis. 77:537.
2. Dutky, E. M., and Wolkow, P. 1994. First report of Fusarium wilt of basil in Maryland. Plant Dis. 78:1217.

3. Elmer, W. H., Wick, R. L., and Haviland, P. 1994. Vegetative compatibility among Fusarium oxysporum f. sp. basilicum isolates recovered from basil seed and infected plants. Plant Dis. 78:789-791.

4. Gamliel, A., Katan, T., Yunis, H., and Katan, J. 1996. Fusarium wilt and crown rot of sweet basil: Involvement of soilborne and airborne inoculum. Phytopathology 86:56-62.

5. Garibaldi, A., Gullino, M. L., and Minuto, G. 1997. Diseases of basil and their management. Plant Dis. 81:124-132.

6. Grasso, S. 1975. Un avvizzimento del basilico da Fusarium oxysporum. Inf. Fitopatol. 25:5-7.

7. Holcomb, G. E., and Reed, M. J. 1994. First report of Fusarium wilt of basil in Louisiana. Plant Dis. 78:1218.

8. Katan, T., Gamliel, A., and Katan, J. 1996 Vegetative compatibility of Fusarium oxysporum from sweet basil in Israel. Plant Pathol. 45:656-661.

9. Keinath, A. P. 1994. Pathogenicity and host range of Fusarium oxysporum from sweet basil and evaluation of disease control methods. Plant Dis. 78:1211-1215.

10. Kistler, H. C., Alabouvette, C., Baayen, R. P., Bentley, S., Brayford, D., Coddington, A., Correll, J., Daboussi, M.-J., Elias, K. Fernandez, D., Gordon, T. R., Katan, T., Kim, H. G., Leslie, J. F., Martyn, R. D., Migheli, Q., Moore, N. Y., O’Donnell, K. Ploetz, R. C., Rutherford, M. A., Summerell, B., Waalwijk, C., and Woo, S. 1998 Systematic numbering of vegetative compatibility groups in the plant pathogenic fungus Fusarium oxysporum. Phytopathology 88:30-32.

11. Komada, H. 1975. Development of a selective medium for quantitative isolation of Fusarium oxysporum from natural soils. Rev. Plant Prot. Res. 8:114-124.

12. Kvartskhava, P. A. 1957. On a study of the infectious wilting (fusariosis) in eugenol Basil. Trud. Sukhumsk. Opyt. Sta. Éfiromas Kul't. 2:101-113 (in R. A. M. 38, 613).

13. Maniatis, T., Fritsch, E. F., and Sambrook, J. 1982. Molecular Cloning: A Laboratory Manual. Cold Spring Harbor Laboratory, Cold Spring Harbor, NY.

14. Martini, P., and Gullino, M. L. 1991. Trasmissibilità per seme di Fusarium oxysporum f. sp. basilicum, agente della tracheofusariosi del basilico. Inf. Fitopatol. 41:59-61.

15. Mercier, S., and Pionnat, J. C. 1982. Présence en France de la fusariose vasculaire du basilic. C. R. Seances Acad. Agric. Fr. 68:416-419.

16. Migheli, Q., and Cavallarin, L. 1994. Characterization of antagonistic and pathogenic Fusarium oxysporum isolates by random amplification of polymorphic DNA. Mol. Biotechnol. 2:197-200

17. Migheli, Q., Friard, O., Del Tedesco, D., Musso, M. R., and Gullino M. L. 1996. Stability of transformed antagonistic Fusarium oxysporum strains in vitro and in soil microcosms. Mol. Ecol. 5:641-649.

18. Minuto, A., Garibaldi, A., and Gullino, M. L. 1994. Biological control of Fusarium wilt of basil (Ocimum basilicum L.). Proc. BCPC 1994 6D-18:811-816.

19. Minuto, A., Minuto, G., Migheli, Q., Mocioni, M., and Gullino, M. L. 1997. Effect of antagonistic Fusarium spp. and of different commercial biofungicide formulations on Fusarium wilt of basil (Ocimum basilicum L.). Crop Prot. 16:765-769.

20. Minuto, A., Mocioni, M., and Garibaldi, A. 1995. Preliminary trials on biological control of Fusarium wilt of basil. Acta Hortic. 
382:173-177.

21. Reuveni, R., Dudai, N., Putievsky, E., Elmer, W. H., and Wick, R. L. 1997. Evaluation and identification of basil germ plasm for resistance to Fusarium oxysporum f. sp. basilicum. Plant Dis. 81:1077-1081.

22. Tamietti, G., and Matta, A. 1989. La tra- cheomicosi del basilico causata da Fusarium oxysporum f. sp. basilicum in Liguria. Difesa Piante 12:213-220.

23. Welsh, J., and McClelland, M. 1990. Fingerprinting genomes using PCR with arbitrary primers. Nucleic Acids Res. 18:7213-7218.

24. Wick, R. L., and Haviland, P. 1992. Occur- rence of Fusarium wilt of basil in the United States. Plant Dis. 76:323.

25. Williams, J. G. K., Kubelik, A. R., Livak, K. L., Rafalski, J. A., and Tingey, S. V. 1990. DNA polymorphisms amplified by arbitrary primers are useful as genetic markers. Nucleic Acids Res. 18:6531-6535. 